\title{
NUTRITIONAL STATUS AND QUALITY OF LIFE OF PEOPLE WITH DIABETES MELLITUS TYPE 2
}

\author{
Sasmiyanto 1), Nora Azizah Yuliani 2) \\ 1) Lecturer of Faculty of Health Science, University of Muhammadiyah Jember \\ 2) Student of Faculty of Health Science, University of Muhammadiyah Jember \\ Corresponding e-mail : sasmiyanto1@gmail.com
}

\begin{abstract}
BACKGROUND: Diabetes mellitus is a kind of metabolic disease characterized by increasing of blood glucose related to insulin resistence. Controlling the risk factor has prooven to be effective in controlling the pathophysiolgy of the disease. In the other hand, diabetes mellitus has an effect in quality of life. The purpose of this research are to find out the correlational relationship between the nutritional status and quality of life of people with diabetes mellitus.

SUBJECT AND METHODE : Its'a acorrelational research conducted by cross sectional approach. The population are people with diabetes who came to Holistic Care clinic at December - Februari 2019 counted 100 people. There are 30 respondents taken by simple randim sampling. The data taken using a questionnaire Revised Diabetes Quality of Life (Revised DqoL). Then the data analysed by using by statistical analysis using Spearman correlational test.

RESULT : It show that the mean of respondent's body mass index as nutritional status were 32,606 which mean that the respondents has ideal body weight. Then the mean of DQoL show 3,66 means that respondent has good quality of life. Statistical analysis show $p$ value 0,587 means that there are no significant correlational between nutritional status and quality of life people with diabetes mellitus. DISCUSSION : Psychological and social aspect has bigger part in forming quality of life in people with diabetes.
\end{abstract}

Key words : nutritional status, quality of life, diabetes mellitus

\section{INTRODUCTION}

Diabetes mellitus (DM) is one common metabolic disease in Indonesia. It is divided into two type. DM type 1 or IDDM is metabolic disfunction that occurs due to damage of pancreatic beta cells so that the body does not secrete insulin at all and the client absolutely needs insulin. Whereas type 2 diabetes mellitus or NIDDM occurs due to pancreatic incompetence in secreting insulin which is needed in glucose metabolism so that it is characterized by an increase in abnormal glucose levels in the blood.

The incidence of diabetes mellitus continues to increase every year. The last estimate of the International Diabetic Federation (IDF) in 2013 was 382 million diabetic worldwide. Of the 382 million people 175 million of them have not been diagnosed so that they are threatened to progresively develop into unconsious and uncomplicated complications. The result of a household health survey (SKRT) in 2001 found the prevalence of people with diabetes mellitus in the population age 25-64 years old in Java and bali by 7.5\%. The results of the Riskesdas 2013 mention the proportion of people with diabetes mellitus of $6.9 \%$ (Infodatin DM, 2014). 
The development of diabetes mellitus in Indonesia has increased every year. Azila (2016) said basd on IDF data in 2011 Indonesia renked tenth in the world. Data released by BPS in 2003 totaled 133 million people. The prevalence of diabetic patients will contibue to increase and it is predicted that by 2030 it will reach 21.3 million. East Java Province is one of the provinces with type 2 diabetes mellitus prevalence above the national prevalence, reaching $1.3 \%$ with a fairly high number of patient. In 2012 in Jember District there were 8,619 people with diabetes mellitus.

In the course of the diabetes mellitus is also known as silent killer due to the complication it causes. Complication of diabetes mellitus can cause visual disturbances, heart disease, renal failure, impotence, difficult to heal wounds, lung infection, stroke, and so forth. Even diabetes mellitus can cause amputation in limbs.

Various studies have proven that diabetes mellitus has various risk factors such as obesity/ body mass index, hypertension, cholesterolm physical activity. Control of risk factorrs have been shown to influence the proccess of controling the course of diabetes mellitus. In the other hand, diabetes mellitus which is a chronic disease will affect the quality of life. Quality of life is an individual's perception of his position in life in the context of culture and value systems and their religion to existing goals, expecatation and standards.

The results of previous studies conducted by Azzila (2016) about quality of life of people with diabetes mellitus stated that $52.6 \%$ people with diabetes has good quality of life. Another study cinducted by Meidikayanti and Wahyuni (2017) shoe significant correlationship between familiy support and quality of life of people with diabetes mellitus. Alcubierre et al (2016) also cunduct a study and stated that obedience in mediteran diet does not have significant affect to general quality of life of people with diabetes but has som significant correlationship to some dimention of people with diabetes mellitus.

The treatment of diabetes mellitus consist of 4 main pillars which is education, medical nutritional therapy, exercose and medication. Those 4 pillars are conduct to control the diabetes mellitus risk factors to prevent the complication. In another words, obedience to medical treatment programme will conrol diabetical risk factors to improve health perception of people with diabetes mellitus that will lead them to form a good quality of life. That is why we are interst in conducting the study about the correlationship between nutritional status and quality of life if people with diabetes mellitus.

\section{METHODE}

This is a correlational study conducted by cross sectional approach. The population are people with diabetes who came to Holistic Care clinic at December - Februari 2019 counted 100 people. There are 30 respondents taken by simple randim sampling. The data taken using a questionnaire Revised Diabetes Quality of Life (Revised DqoL). Then the data analysed by using by statistical analysis using Spearman correlational test.

\section{RESULT AND DISCUSSION}


The data collection were held at May 2019 involving 30 respondents which is the client of Holistic care Clinic Bondowoso. The characteristic of respondents was shown as follow :

Table 1. General Caharacteristics of Respondents (Primary Data, 2019)

\begin{tabular}{|c|c|c|}
\hline Characteristics & Frequency & Percentage \\
\hline \multicolumn{3}{|l|}{ Age (years old) } \\
\hline $31-40$ & 3 & 10 \\
\hline $40-50$ & 10 & 33 \\
\hline $50-60$ & 15 & 50 \\
\hline $60-70$ & 2 & 7 \\
\hline \multicolumn{3}{|l|}{ Gender } \\
\hline Male & 4 & 13 \\
\hline Female & 26 & 87 \\
\hline \multicolumn{3}{|l|}{ Level of education } \\
\hline Elementary school & 3 & 10 \\
\hline Junior high school & 8 & 27 \\
\hline Senior high school & 17 & 66 \\
\hline College & 2 & 7 \\
\hline \multicolumn{3}{|l|}{ Occupation } \\
\hline Goverment employee & 2 & 7 \\
\hline Enterpreneur & 20 & 67 \\
\hline Labor & 3 & 10 \\
\hline Housewife & 5 & 16 \\
\hline \multicolumn{3}{|l|}{ Marital status } \\
\hline Married & 30 & 100 \\
\hline \multicolumn{3}{|l|}{ Health Insurance } \\
\hline Yes & 10 & 33 \\
\hline No & 20 & 67 \\
\hline \multicolumn{3}{|l|}{ Comorbid } \\
\hline Yes & 10 & 33 \\
\hline No & 20 & 67 \\
\hline \multicolumn{3}{|l|}{ Complication } \\
\hline Yes & 20 & 67 \\
\hline No & 10 & 33 \\
\hline \multicolumn{3}{|l|}{ Length of illness } \\
\hline Less than a year & 5 & 16 \\
\hline More than a year & 25 & 84 \\
\hline \multicolumn{3}{|l|}{ Fasting blood glucose } \\
\hline$<120 \mathrm{mg} / \mathrm{dl}$ & 8 & 27 \\
\hline$>120 \mathrm{mg} / \mathrm{dl}$ & 22 & 73 \\
\hline
\end{tabular}

According to the data on table 1 we see that majority of respondents are $50-60$ years old, female, graduate from high school, working as enterpreneur, has no health insurance, no comorbid, has complication which is diabetic foot, got diabetes mellitus for more than a year and has fasting blood glucose level higher than $120 \mathrm{mg} / \mathrm{dl}$. All of respondents were married. 


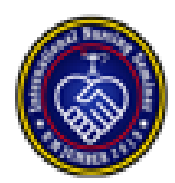

Table 2. Average of Body Mass Index (BMI) and Quality of Life (QoL) of Respondents (Primary Data, 2019)

\begin{tabular}{lc}
\hline \multicolumn{1}{c}{ Parameter } & Mean \\
\hline Body Mass Index & $23,609 \pm 4,4177$ \\
Quality of Life & $3,66 \pm 0,515$ \\
Satisfaction about diabetes mellitus & $3,88 \pm 0,498$ \\
Social perspective due to diabetes mellitus & $3,25 \pm 0,926$ \\
Diabetes mellitus perspective & $3,85 \pm 0,671$ \\
Impact of diabetes mellitus & $3,56 \pm 0,794$ \\
\hline
\end{tabular}

According to the data in table 2 we see that the average of BMI is 23.609 means that the $\mathrm{BMI}$ of respondents is considered to be normal. Diabetes mellitus is one of teh disease that affected by obesity, especially central obesity. It causes by insulin resistance due to excess fat accumulutaion in the body that will lead to the increase of blood glucose. These result study show the mean of BMI of respondents is 23.609 which mean the BMI is normal.

Majority of the respondentsare $5-60$ years old. This age are at risk to have obesity compared with the age group under 40 . But these study is shown different result, it can be happen due to majority of respondents has diabetes mellitus for more than a year. History of having diabetes mellitus for a long time will make a possibility to increase the catabolism of glucose and fat as source of energy to occur.

The other factors that affect the bMl is physical activity. Majority of respondents is working. Their occupation a little bit affected their physical activity. Most of respondents are working as an enterpreneur. These kind of job will make them possible to mobilization so that they will actively move. These study is in line with the study of Fitriyani (2012) which stated taht occupatioin and physical activity are affected the BMI.

Beside that respondents are the client of Holistic Crae Clinic Bondowoso. They often received health eduaction about diabetes mellitus or health in general. Suppoted by the level of education of respondents. Majority of respondents are graduated from high school so it will make them easy in receiving the new information.

Quality of life of respondents in general has the average score 3.66 bigger than median value 2.5 so that it can be conclude that the respondents has good quality of life. Quality of life is an individual's perception of his position in life in the context of culture and value systems and their religion to existing goals, expecatation and standards. Quality of life is also multidimensional concepts involving physical. Social and psychological aspects that connected with illness and theraphy.

Satria in Dzuzturia (2012) stated that diabetes mellitus is a chronic disease need long term theraphy. Diabetes mellitus complication is an impact of physical problem that faced by people with diabetes mellitus. Another problem due to diabetes mellitus that could have big impact to quality of life of people with diabetes is psychological burden from the people with diabetes mellitus itself and also their family that can be seen though their negative emotional behavior like rejection and 
depression. Beside that the decreasing of productivity and socail interaction due to complication of diabetes mellitus.

The results show the average score of quality of life show that respondents has good quality of life. Some factors contribute to quality of life is age. Majority of respondents are $50-60$ years old, in this phase, individuals has pass the young age, so that in this periode the individuals has pass the phase and evaluate live they are live in positively compared with the younger one. This in line with the study results of Wahyuni (2014) which is said that quality of life according to the characteristics of people with type 2 diabetes mellitus stated that older individuals has better quality of life.

Beside that the repondents's occupation as an enterpreneur making them possible more intens in doing mobilization, met others and make an achievement. When individuals has a job then it will make him aould afford the treatment he need to maintain his health status. Then it will bring positive effect to the perception of quality of life than the job less respondents. Marital status is also could increase the quality of liife of people with diabetes since marriage could predetermine family support during the treatment.

Level education of respondents is also contribute to the perception of quality of life. Most of respondents are graduated from high school. High educatuion could stimulate individuals to find more information about the disease they have got. The observation show that the opennes attitudes of health providers also encourage the client to not to be emabarassed to ask about their disease or the treatment.

Wahyuni (2014) stated that lenght of having diabetes mellitus is also affect the quality of life due to the anxiety. Periode of having disease and duration of treatment are affected to functional capacity, psychological capacity health status and propslerity level of respondents. Physiological changes due to long term hyperglicemia will lead to microvasculer and macrovascular complication. Majority of respondents are having diabetic foot but it is not decreased their quality of life. It is because of advance wound care technicque applied by health providers to improve their condition. The wound heals quickly coupled by the acceptance of tehir condition coul improve the quality of life.

Statistical analysis using Spearman correlation technicque show $p$ value of 0.587 greater than a 0.05 means that there is no significant correlation between nutritional status and quality of life of people with diabetes mellitus. Nutritional status is parameters in fulfill nutriotional needs indicated by the weight and height the individuals. Nutritional status is also define as health status which is make up from the balance between the need and input of the nutrients, measuring nutritional status will describe to us about a risk condition of all disease, which is obesity. Waspadji, in Adnan (2013) said that central obesity is an etiological factors that could lead to diabetes mellitus. Fat accumulation in the body coul lead to insulin resistance that make the blood glucose is about to increase. When blood glucose are increase the patient will have hyperglicemia which coul worse his health status.

There is no significant correlation between nutritioanl status and quality if life could occurs due to so many factors. Qulaity of life is formed of physical, psychological, activity, social, and environmetal aspects. BMI is one of indicators that could affect physical health which is one of domains in quality of life trough blood glucose regulation. But psycological and social aspect has more part in determining the quality of life in people with diabetes mellitus. 
Some respondents are having normal BMI and some are havin diabetic foot too. When the diabetic foot is not care properly it wil affect the body image and social interaction so it will worsen the quality of life. But in the location of this study, the health care provider has provide wound care for diabetic foot and the wound are become better. The improved wound condition will help respondents to have personal confidence to socially interact and has some hope to be back in normal life again.

\section{CONCLUSION AND RECOMMENDATION}

From the results above it can be concluded that majority of respondents has normal body mass index and has a good quality of life. But stattistical analysis show no significant correlationship between nutritional status and quality of life of peope with diabetes.

From the results above the recommendation of this study is that the client should has a full commitment during the period of treatment so that the diabetic foot will heal and they could make an intens social relationship that coul maintain their quality of life.

\section{REFERENCE}

Adnan, M., Mulyati, T. \& Isworo, J., 2013. Hubungan Indeks Massa Tubuh dengan Kadar Gula Darah Penderita Diabetes Mellitus Tipe 2 Rawat Jalan di RS Tugurejo Semarang. Jurnal Gizi Universitas Muhammadiyah Semarang, 2(1), pp. 18 - 26.

Alcubierre, N. et al., 2016. Relationship of Adherence to Mediteranian Diet With Health Related Quality of Life and Treatment Satisfaction inPatient with Type 2 Diabetes Mellitus : A Post hoc Analysis of A Cross Sectional Study. Health and Quality of Llfe Outcomes, 14(69), pp. 1 - 6.

Asrimaidaliza, 2011. Asupan Gizi dan Penyakit Diabetes Mellitus. Jurnal Kesehatan Masyarakat, 6(1), pp. 36-41.

Azzila, A., 2016. Gambaran Kualitas Hidup Pasien Diabetes Mellitus Tipe 2 di Poli InternaRSD dr. Subandi Jember, Jember: Universitas Jember.

Babazadeh, T. et al., 2017. Association of Self care Behaviors and Quality of Life among Type 2 Diabetes Mellitus : Chaldohan County Iran. DMJ , 2(13), pp. 449 - 456.

Bujang, M. et al., 2018. A FRevised Version of Diabetes Quality of Life Instrument Maintaning Domains for Satisfacton, Impact, and Worry. HIndawi, Journal of Diabetic Resesarch, 2(3), pp. 1 - 10.

Dzusturia, D., 2016. Pengaruh Diabetes Self Management Education and Support (DSME/S) terhadap Kualitas Hidup pada Pasien Diabetes Mellitus Tipe 2 di Wilayah Kerja Puskesmas Patrang Kabupaten Jember, Jember: Universitas Jember. 
Meidikayanti, W. \& Wahyuni, C., 2017. Hubungan Dukungan Keluarga dengan Kualitas Hidup Penderita DM tipe 2 di Puskesmas Pademawu. Jurnal Berkala Epidemiologi, 5(2), pp. 240-252.

RI, K., 2016. Situasi dan Analisis Diabetes. Pusat Data dan Informasi Kementrian Kesehatan RI, 1(1), pp. 1 - 8.

Suahema, Asdi, A. \& Pangastutu, R., 2010. Pengendalian Status Gizi, Kadar Glukosa Darah, dan Tekanan Darah Melalui Terapi Gizi Medis pada Pasien Diabetes Mellitus Tipe 2 Rawat Jalan di RSU Mataram NTB. Jurnal Gizi Klinik Indonesia, 7(2), pp. $4-57$. 
